\title{
Classroom Discourse Analysis in EFL Elementary Lessons
}

\author{
Dorota Domalewska
}

\begin{abstract}
The present study is an attempt to confront the problem of many Thai students' failure to communicate fluently and accurately in English. For this reason the study investigates the patterns of teacher-student interaction in beginner EFL (English as a Foreign Language) lessons in a Thai elementary school. The analysis of classroom discourse shows that one-way communication prevails in the lessons with the teachers leading teacher-fronted discussion and students listening and then either repeating after the teacher or responding briefly. If the students are engaged in a discussion, they are asked mainly comprehension, assent or educational (grammar and vocabulary) questions. Furthermore, an examination of the teachers' and students' verbal behaviors shows frequent code-switching practices.
\end{abstract}

Index Terms-Classroom discourse analysis, code switching, elementary education, English as a foreign language.

\section{INTRODUCTION}

Formal instruction accelerates the acquisition of the target language and makes it possible for learners to achieve higher level of proficiency. Having been exposed to rich input in English and having learned the language for many years, it should not be difficult for Thai students to communicate in English. Nevertheless, many learners cannot speak and write fluently and accurately in English. Thus, the problem of many students' failure to communicate effectively needs to be confronted.

Successful language learning depends on classroom communication, i.e. interaction learners engage in with their teacher and other learners. The discourse among students and the teacher and among students themselves is central for foreign language learning as it contextualizes learning experiences while active participation in classroom discourse engages learners in the learning process.

\section{Classroom Discourse}

A characteristic feature of classroom discourse is the teacher's control of the interaction. A large body of research proves the unequal roles of participants in classroom communication with the teacher managing the conversation and turn-taking [1]. However, the control over the classroom discourse leads to limited learning as there is no place for meaningful, spontaneous and natural interaction. Students can only acquire the language through involvement in interactions and relationships formed when they take part in

Manuscript received October 10, 2014; revised January 14, 2015.

Dorota Domalewska is with Rangsit University, Pathum Thani, Thailand (e-mail: dorota@outlook.co.th). communication. Language thus activated and internalized becomes part of the students' cognitive resources [2]. Learning needs to be meaningful as it allows "new pieces of information [to be] attached to existing knowledge so that a new, meaningful whole, like the completed puzzle, is formed" [3]. Learning needs to be based on the processes of assimilation, accommodation, developing meaningful cognitive sets (i.e. forming logical connection and organization in the material), and using advanced organizers (i.e. general concepts that help the learner to organize and understand new material). Meaningful learning allows the information to be retained for a longer period of time; the information may be retrieved faster; furthermore, the student's cognitive structure is developed.

Teachers tend to limit speaking opportunities for their students by asking questions that fulfil educational goals but prevent interlocutors from developing conversation and also violate pragmatic conventions of conversation [4]. Other studies [5]-[7] prove that classroom discourse is limited to teacher-initiated questions are to a great extent display questions that are difficult to answer due to a short time allowed for response, and the third turn is merely a simple feedback.

However, teachers need to understand that because teacher-fronted activities dominate the lesson, they should support learning by proper use of questions. The study [8] proves that teacher-initiated questions may develop collaboration, boost comprehension and scaffold L2 learning whereas [9] show that the teachers who aim at involving the students in meaningful interaction help to develop positive social affective relationships among them, which, in turn, supports the learners' cognitive development. According to the socio-cultural theory, learning and cognitive development take place due to social interaction, e.g. between the learner and a more knowledgeable other (a teacher or a classmate) in the zone of proximal development by building a form of scaffolding, i.e. by simplifying tasks, helping to find solutions, drawing the learner's attention to an important element of the language, negotiating the meaning. According to the Interaction Hypothesis [10], learning is enhanced when learners negotiate meaning with other speakers; feedback students receive (e.g. from a teacher who acts as a facilitator) helps to draw their attention to the differences between their interlanguage and L1 forms; hence, they may notice the areas that need improvement. Swain [11] is another researcher who emphasizes the importance of interaction as a facilitating factor in the process of learning a foreign language. In her Comprehensible Output Hypothesis she maintains that linguistic development may be achieved thanks to language production, which forces students to use their linguistic abilities in order to be correctly understood. 


\section{Code Switching In Classroom Discourse}

A large body of research shows that code switching is a common classroom practice. Code switching is the alternating use of two or more languages in a single conversation. It is used for numerous social and educational purposes: linguistic insecurity, topic switch (i.e. language choice is done according to the topic that is discussed, e.g. grammar explanation or giving instructions), and repetitive function (i.e. monitoring or helping the students and giving explanation). Other reasons for language alternations are affective function (i.e. expressing emotions) and socializing function (i.e. using L1 to mark solidarity and friendship with the students) [12], [13]. The meaningful use of L1 in the classroom may enhance rather than impede L2 acquisition through emphasizing similarities and differences between L1 and L2, development of linguistic awareness, and assimilation of new concepts [14]. Moreover, a number of researchers [14], [15] claim that the two languages are not separate but rather linked in the learner's mind in vocabulary, syntax, phonology and pragmatics. However, it needs to be stressed that the target language should dominate in the classroom.

\section{METHOD}

\section{A. Research Objectives}

Taking into consideration the importance of classroom discourse, the present study sets out to investigate the patterns of teacher - students interaction. There is a large body of research that provides insight into classroom discourse; however, the present study focuses on the nature of teacher student interaction and patterns of language use in order to make both teaching and learning more effective. The following research questions guided the study: (1) what is the nature of classroom discourse; (2) to what extent does the code switching take place.

\section{B. Participants}

The present study draws on data collected in 3 beginner classes of grade 3 students of English as a foreign language at a Thai elementary school. A total of seven lessons were observed. The total number of participants was 105 students. The classes were run by 2 native speaker female teachers $(5$ lessons) and a Thai male teacher (2 lessons).

\section{Design and Procedure}

The data collection followed a qualitative perspective that uses quantitative method of data collection [16]; data collection techniques include structured classroom observation, field notes, and audio recordings. Altogether seven lessons were observed; seven hours of classroom discourse were recorded in order to facilitate the analysis. All of the recorded materials have been transcribed and used for analysis. Structured observations allow to generate numerical data from the observations, which facilitates the analysis of patterns of classroom discourse [17]. Observations were entered on an observation schedule that involved predetermined categories. Classroom discourse was analysed in 30-second time interval; however, the categories were not discrete, e.g. both the teacher and student could speak in the same 30-second time interval. The data were classified into the following categories: teacher and student talk time, language used in the lesson, the moments when Thai and English are used (repeating, giving instructions, explanation, translation, praise, and response).

\section{RESUlts}

Through classroom observation and transcription analysis, it could be seen that the lessons are teacher-centered conducted in lockstep; Fig. 1 presents the distribution of teacher talk and student talk.

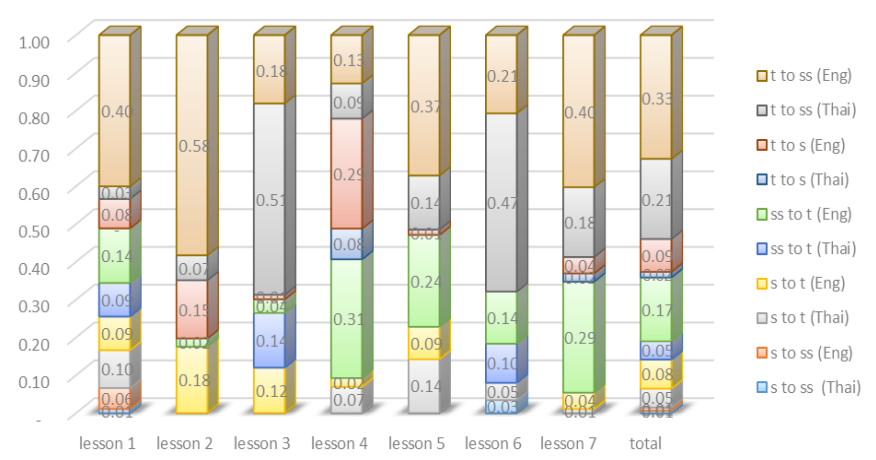

Fig. 1. Teacher talk time and student talk time.

As displayed in Fig. 1, teacher talk time takes almost $70 \%$ of lesson time. Student talk time takes a third of the lesson time out of which most time is taken by chorus repetition (0.19 of lesson time) (see Fig. 2). Lockstep teaching dominates in the lesson due to a large number of students (30 plus) in each class. The addressee of the utterances has also been detected in order to clearly indicate to whom the teachers' and students' utterances are directed. All teachers were observed to produce multi-addressee utterances; more than half of teacher talk is directed at all students. In total only $0.11 \%$ of teacher talk time is directed at individual students. Further investigation of classroom data indicates that choral repetition was the dominant teaching method. In one lesson only one communicative activity was introduced, namely the students were engaged in group work in order to practice new structures and vocabulary (see Fig. 2).

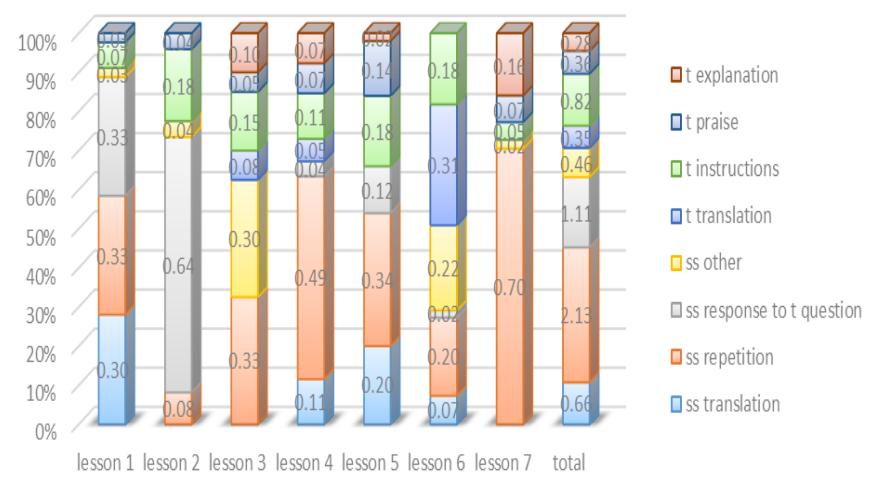

Fig. 2. Function of teacher and student talk.

Fig. 2 clearly shows that choral repetition is the dominant activity in the lesson when the students are asked to repeat sentences and shorter dialogues after the teacher. This technique is not merely a drill followed by other 
communicative activities, but a predominant teaching method interspersed with translation or a short question and answer drill. There are several discourse strategies the teachers use in the lessons. Most of the time the teachers direct their talk at the whole class, but, as it has already been mentioned, the teachers stay with a single student for $0.11 \%$ of class time (see Fig. 1). Another strategy the teachers use is giving positive feedback and praising students thus supporting and encouraging them to do their utmost in the lesson.

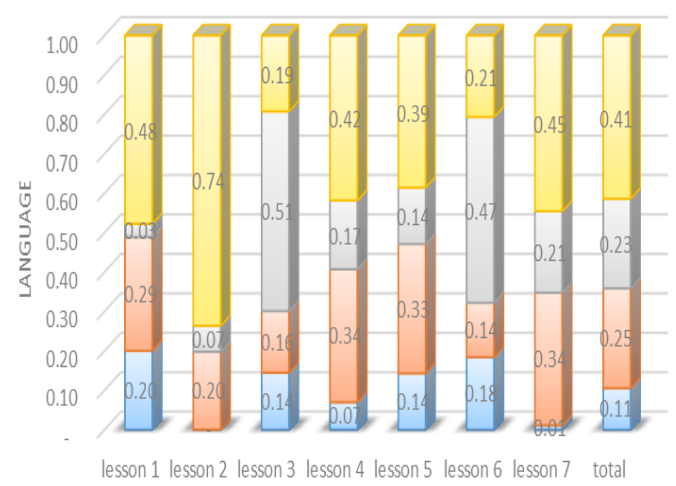

口English (Teacher) uThai (Teacher) QEnglish (students) 口Thai (students)

Fig. 3. Code switching practices.

Fig. 3 shows code switching practices both teachers and students make use of in the lesson. At a first glimpse it can be clearly seen that English is the dominant language of the lesson, but still the native language plays a very important role (on average a quarter of lesson time is in Thai, but in some lessons as much as half of the lesson is in Thai). Further analysis of classroom data reveals that the teachers use code switching for various educational purposes: to provide explanation, instructions or translation; whereas, the students resort to their native language mainly when they are prompted by the teacher in order to translated lexis or sentences.

\section{CONCLUSION}

The analysis of classroom discourse shows that one-way communication prevails in the lessons with the teachers leading teacher-fronted discussion and students listening and then either repeating or responding briefly. The teachers provide the only authentic language input and classroom materials in the observed lessons are limited to the textbook. Given that the major driving force for L2 learning is exposure to language input, the impoverished input the students have received cannot lead to fast rate of acquisition. Furthermore, the students are not involved in high-level discourse. Rather, strict teacher control over the lesson limits their speaking opportunities and autonomy. If the students are engaged in a discussion, they are asked mainly comprehension, assent or educational (grammar and vocabulary) questions, which results in limited conversation. Reference [4] likewise found that discourse strategies used by teachers limit student participation and restrict turn-taking in conversation. The present study shows that the third turn in conversation sequence is limited to a short feedback given by the teachers, most frequently a positive comment or correction, which is supported by other studies [6], [7]. Traditional lockstep teaching used by the teachers results in the lack of individualized instruction as well as the lack communicative and cooperative activities. The students are rarely invited to articulate their opinions and explanations. Finally, their answers are implied by the type of question the teacher asks. Therefore, their learning is limited as they are not supported to negotiate meaning nor link new knowledge to the already existing schemata [2], [3]. The students are just passive recipients of information presented by the teacher.

An examination of the teachers' and students' verbal behaviors shows frequent code-switching practices. Further investigation of teacher discourse indicates that the native language is used in order to provide explanation, instruction or translation, which is in line with studies [13] and [12]. Learners of foreign languages naturally search for clear and unambiguous explanations of new concepts; they want to make sure they have correctly understood the new material. That is why they so often fall back on their mother tongue, as this is the only resource they can rely on. Furthermore, learners rely on the knowledge they have already acquired in order to facilitate the learning process since learning is a process of assimilating new information into the pre-existing cognitive schemas. For foreign language learners their L1 is a basis on which they naturally and unconsciously build L2 system; their L1 competence is the instrument they can use to facilitate understanding. Thus, L2 competence can be developed on the ground common for L1 and L2 by assimilating new rules in L2 into the existing L1 competence. Furthermore, L1 and L2 systems do not form distinct language system in the mind, but they are connected in vocabulary, syntax, phonology, and in pragmatics [14].

\section{REFERENCES}

[1] S. Walsh, Exploring Classroom Discourse: Language in Action, London and New York: Routledge, 2011.

[2] J. J. Thoms, "Classroom discourse in foreign language classrooms: A review of the literature," Foreign Language Annals, vol. 45, pp. 8-27, Jan. 2012.

[3] C. M. S. Semonsky and M. A. Spielberger, Early Language Learning: A Model for Success, the United States of America: Information Age Publishing Inc., 2004, ch. 2.

[4] J. K. Hall, "Aw, man where you going? Classroom interaction and the development of L2 interactional competence," Issues in Applied linguistics, vol. 2, pp. 37-62, Dec. 1995.

[5] F. Smith, F. Hardman, K. Wall, and M. Mroz, "Interactive whole class teaching in the national literacy and Numercy strategies," British Educational Research Journal, vol. 30, pp. 395-411, Oct. 2004.

[6] S. Lyle, "Dialogic teaching: Discussing theoretical contexts and reviewing evidence from classroom practice," Language and Education, vol. 22, pp. 222-240, Dec. 2008.

[7] D. Myhill, "Talk, talk, talk: Teaching and learning in whole class discourse," Research Papers in Education, vol. 21, pp. 19-41, Aug. 2006.

[8] D. E. McCormick and R. Donato, "Teacher questions as scaffolded assistance," in Second and Foreign Language Learning Through Classroom Interaction, J. K. Hall and L. Stoops Verplaetse, Eds. Oxon, New York: Lawrence Erlbaum Associates, 2000, ch. 3, pp. 183-201.

[9] D. Beyazkurk and J. E. Kesner, "Teacher-child relationships in Turkish and United States schools: A cross-cultural study," International Education Journal, vol. 6, pp. 547-554, Dec. 2005.

[10] A. Mackey, J. Philp, T. Egi, A. Fujii, and T, Tatsumi, "Individual differences in working memory, noticing of interactional feedback and L2 development," in Individual Differences and Instructed Language Learning, P. Robinson, Ed. Amsterdam, Philadelphia: John Benjamins Publishing Company, 2002, ch. 9.

[11] M. Swain, "Communicative competence: Some roles of comprehensible input and comprehensible output in its development," in Input and Second Language Acquisition, S. Gass and C. Madden, Eds. Rowley, MA: Newbury House, 1985, ch. 14. 
[12] S. Greggio and G. Gil, "Teacher's and learner's use of code switching in the English as a foreign language classroom: A qualitative study," Linguagem \& Ensino, vol. 10, pp. 371-393, Jul. 2007.

[13] D. Moore, "Code-switching and learning in the classroom," International Journal of Bilingual Education and Bilingualism, vol. 5 , pp. 279-293, Mar. 2002.

[14] V. Cook, "Using the first language in the classroom," Canadian Modern Language Review/La Revue Canadienne des Langues Vivantes, vol. 57, pp. 402-423, Mar. 2001.

[15] R. Sanchez-Casas and J. E. Garcia-Albea, "The representation of cognate and noncognate words in bilingual memory," in Handbook of Bilingualism: Psycholinguistic Approaches, J. F. Kroll and A. M. B. de Groot, Eds. New York: Oxford University Press, 2005, ch. 11.

[16] D. Allwright and K. M. Bailey, Focus on the Language Classroom: An Introduction to Classroom Research for Language Teachers, Cambridge: Cambridge University Press, 1991.
[17] K. F. Punch, Introduction to Research Methods in Education, London Sage, 2009.

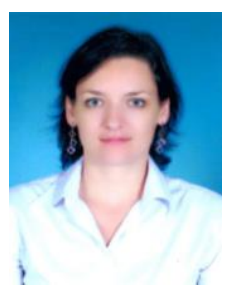

Dorota Domalewska was born in Warsaw, Poland in 1978, she holds a Ph.D. degree in applied linguistics from University of Warsaw, Poland in 2009. She has completed her master's degree in applied linguistics (English philology) from University of Warsaw, Poland in 2003.

She is a lecturer at Rangsit University, Thailand, where she teaches academic writing, critical reading, and other courses. Her current research interests include foreign language teaching methodology, computer enhanced teaching and learning, media in language education. 